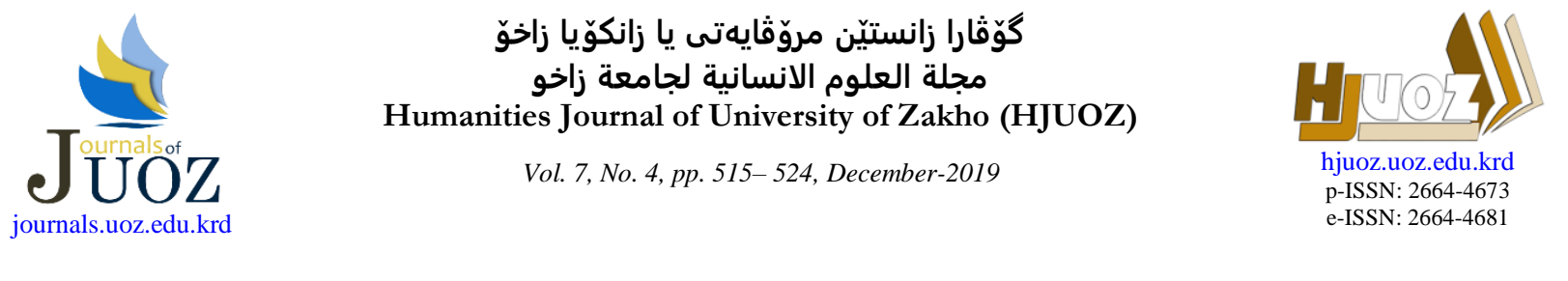

\title{
An Analysis of the Pronouncing of English Monophthongs by Kurdish EFL University Students (Northern Kurmanji Speakers)
}

\author{
Sabah Sulaiman Haji*1, Fakhir Omar Mohammed ${ }^{2}$ \\ ${ }^{1}$ Department of English Language, College of Basic Education, University of Zakho, Kurdistan Region - Iraq. \\ ${ }^{2}$ Department of English Language, Faculty of Humanities, University of Zakho, Kurdistan Region - Iraq.
}

Received: 09. 2019 / Accepted: 11. 2019 / Published: 12. 2019 https://doi.org/10.26436/hjuoz.2019.7.4.561

\begin{abstract}
:
This study investigated the production of English monophthongs by Kurdish EFL learners at university level. Twenty native speakers of Northern Kurmanci (i.e. NK) undergraduate EFL learners read a list of sixty English words containing all the twelve English monophthongs. Their reading of the words was recorded and then transcribed by the researchers. The recording of each word was listened to several times for detecting mispronunciation of the monophthong vowel in it. After careful examination, results showed that the central vowels were the most problematic sounds for Kurdish EFL learners in terms of pronunciation followed by high back vowels. In principle, participants were expected to have problems with central vowels of English, mainly because they do not exist in their mother language, but the findings indicated that high back vowels also are quite noticeably difficult for them to correctly pronounce, even though these already exist in their mother language, NK Kurdish. The main reasons Kurdish EFL learners mispronounce English monophthong vowels are due to the absence of some of these vowels in their first language and also due to the participants' lack of exposure to and practice of English pronunciation.
\end{abstract}

KEYWORDS: Monophthongs, mispronunciation, phonetics, Northern Kurmanji, EFL, interference, mother language.

\section{Introduction}

The pronunciation of speech sounds (i.e. consonants and vowels) is the most important skill of spoken language. However, mastering the pronunciation of a language is not always an easy task for foreign language learners, especially those whose first language has a totally different sound system and orthography. When it comes to English language pronunciation, EFL learners from around the world in general and in the Northern Kurmanji (hence, NK) dialect in particular have a great deal of difficulty mastering it. This is because of the fact that, in English, words are not always pronounced as they are written. For instance, the word bridge is not pronounced as /bridge/, but /bridz/, and surface is not /su:fasi/, but /'s3:fis/.

\section{Aims of the Study}

Analyses and studies of the phonetic and phonological problems the EFL learners (i.e. the NK university students in the current paper) face are not widespread in a context where Kurdish is the official language and English is the second language. The NK learners have problems with pronouncing the English vowels. Simply, this study investigates:

1. Assessment of the EFL university learners' problems with monophthong vowels.

2. Determination of the most problematic monophthongs for Northern Kurmanci Kurdish EFL learners to pronounce and the underlying factors for that.

\section{Value of the Study}

Lots of research papers have been written on the problems the EFL university students have when learning the English vowels, especially monophthongs. However, the study of pronunciation issues at university level and its related problems need to be further investigated. This is due to existing little pronunciation skills found in the curriculum. To our knowledge, assessing the EFL learners' problems with monophthongs with NK university students has not been tackled before. Therefore, it is very important to explain, assess and measure the learners' problems regarding the pronunciation of monophthongs, determining which types of monophthongs are more problematic for them.

\section{English Monophthongs}

Each language contains its own unique set of sounds. One view comes from a phonetic viewpoint, where vowels are sounds "in which there is no obstruction to the flow of air as it passes from the larynx to the lips" (Roach, 2000: 10). Pronounced within open vocal tract, they are said to be articulated with an open articulation. As the articulators are not involved, the tongue is floating freely around the mouth, not touching other parts of the vocal tract. This makes it harder to describe exactly what is happening in the mouth.

The significance of pronunciation cannot be ignored in the learning process. According to Hago and Khan (2015: 85), "the most important part of learning English as a second language rests on pronunciation". However, such a statement is to an extent considered to be an exaggeration because there is enough research evidence against this argument. Hence, one important fact that explains why pronunciation can be difficult for both native speakers and EFL learners is the correspondence between letters and their sounds. For example, the letter "a" can represent /æ/ in bat, $/ \wedge$ in car, /a: / in half. Also, each vowel sound can be represented in more than one way in spelling: the sound /i:/ can be written as ea in beat, as $e e$ in seen. In order to characterize vowels satisfactorily, the cardinal vowel system, which consists of a set of fixed,

\footnotetext{
* Corresponding Author.
} 
unchanging sounds, was introduced. Theoretically, cardinal vowels do not represent the vowels of any actual language, but the vowels of natural languages can be better described with the help of cardinal vowels. If you learn the cardinal vowels, you are not learning to make English sounds, but you are learning about the range of vowels that the human vocal apparatus can make, and also learning a useful way of describing, classifying and comparing vowels (Abercrombie, 1967: 56-57; Roach, 2000: 12). The cardinal vowels are described below:

1. [i] close front spread vowel

2. [e] close-mid front neutral vowel

3. $[\varepsilon]$ open-mid front neutral vowel

4. [a] open front neutral vowel

5. [a] open back neutral vowel

6. [0] open-mid back rounded vowel

7. [o] close-mid back rounded vowel

8. [u] close back rounded vowel

As it is clear from the above descriptions, the production of vowels mainly depends on (1) tongue position, (2) length and (3) lip-rounding (Roach, 2000: 14-15). Practically, the English vowels can be classified into three types: monophthongs (simple or pure), diphthongs and triphthongs. For the purpose of our study, only the monophthongs are taken into consideration. Monophthongs, which are twelve in number, are called pure because they do not glide (O'Connor, 1980: 79-84; Roach, 2000: 14). That means, the airstream comes out freely from the lungs through the pharynx up to the final outlet, the lips. This is what Abercrombie (1967: 68) claims, stating that a monophthong is "a vowel of constant quality". The English monophthongs are presented in the following figure:

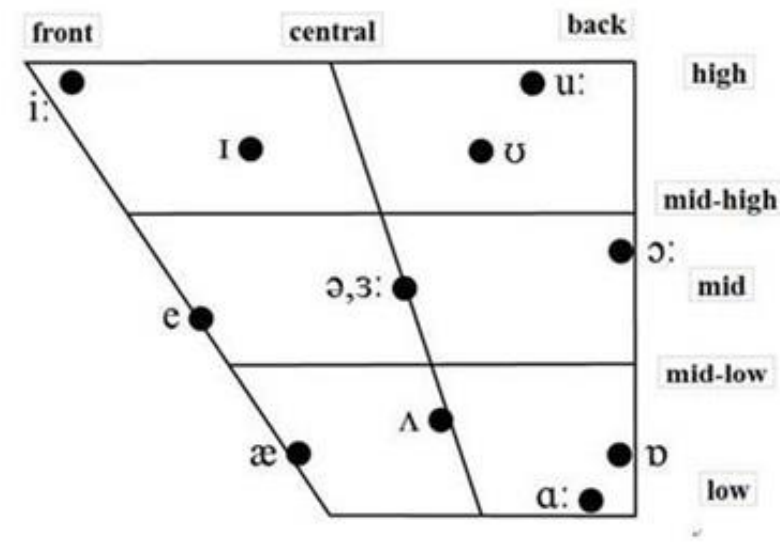

(Ladefoged, 1993: 76).

Figure1: The English Monophthongs

The above figure presents the English monophthongs and their symbols according to the International Phonetic Alphabets (IPA) inventory of vowels. (See Yule, 2006: 38).

\section{Factors Affecting the Pronunciation of English Vowels}

Many linguists and researchers have concluded that the English pronunciation problems among EFL speakers exist in other languages as well. These problems are to an extent the same (Hassan, 2014: 32-34). However, these problems vary according to some notable factors. They are explained below: 1. Mother tongue interference: one of the obvious cases of mother tongue interference is in the area of pronunciation. This can be observed from transferring the pronunciation features of a mother tongue (L1) into another language (L2). L1 interference, in this case, negative interference of the pronunciation aspect of L1 with that of L2 (Munro, 1993: 3961; Piske, et al. 2001: 191-215; Ali, 2013: 497; Matsubara, 2015: 19).

2. Inconsistency of English Vowels: It is clear that each English vowel has one or more than just one pronunciation. So, this causes many difficulties to the learners and leads to mispronunciation. For instance, in the words city /siti/, busy /bızi/, women /wımın/, pretty/priti/, the letters $y, u, o$ and $e$, all stand for the same vowel $/ \mathrm{i} /$. In contrast, in words like, banana /bəna:nə/, bather/beıə/, man /mæn/, many/meni/, the letter $a$ stands for five different vowels. Oftentimes, EFL learners confuse /i/ with /i:/ as in sit/seat pair, /p/ with /au/as in not/note air, $/ \mathfrak{x} /$ with /ei/as in mat/mate pair, and /e/ with /ei/ as in let/late pair. This means that it is not easy to know the exact sounds the letters stand for. (O'Connor, 1980: 8). Simply, the inconsistency of English vowels poses great difficulties for other learners of English language.

3. Influence of spelling pronunciation: there are differences between the spelling systems from one language to another. In NK, learners can easily pronounce a word from a written text. That is, each letter represents one sound, and the relationship between the orthography and the phonology is very easy to distinguish. Many words in English have letters which are not pronounced (Yule, 2006: 25). For example, some words are spelt differently, but sound the same. Words such as rain, rein and reign are pronounced as /remn/.

4. Stress: As it is known, English tends to be a stress-timed language with rhythmic patterns based on a fairly regular recurrence of stressed syllables (Ladefoged, 1993: 249). The Kurdish language tends to give equal weight to each syllable, making the rhythmic patterns appear to be more syllable-timed. Many EFL learners often use the NK rhythmic pattern when speaking English. As a result, even though they can pronounce each English sound correctly, their speech does not sound like English. To predict the place of stress in an English word is not an easy task. This is what Roach (2000: 87) claimed, stating that "it is best to treat stress placement as a property of the individual word, to be learned when the word itself is learned". 5. Intonation: According to Zhang and Ying (2009: 141), "the correctness of pronunciation and intonation directly affects the appropriate communication in conversation". When listening to English, most EFL learners pay more attention to sounds, vocabulary, and grammar. Seldom do they attend to pitch changes. That is, they tend to pronounce each word as clear as possible. This belongs to two major problems: (1) misused intonation patterns and (2) lack of sentence focus, i.e., what sentence pattern is used. Further, it is no surprise that many students speak English simply by applying the rhythmic structure of Kurdish. The result is that they sound monotonous. That is, their voice is rather flat with little or no change in pitch.

\section{Method}

In this part, the method of data collection, which includes the materials that are used for collecting data, participants and the procedures, will be described.

\subsection{Materials}

Samples of pronunciations were repeated as many times as needed. This helped the researchers to identify errors of mispronunciation. Ma (1997: 17) used audio recordings to investigate how native speakers of Mandarin Chinese pronounced five front English vowels, presenting difficulties in pronouncing them. The same materials and tools were used for showing mispronunciation errors done by $20 \mathrm{EFL}$ learners of NK (hence, represented by " $S$ " to stand for student as shown in Appendix II) in the Department of English, Faculty of Humanities at the University of Zakho. The primary resource used for collecting data for this study was a list of sixty English words containing all the twelve English monophthongs (see Appendix I). The idea here was to have participants read the words one at a time while their reading of the words was being recorded to examine their pronunciation of the monophthong vowels. 
All the intended vowels, which were twelve, were present in the wordlist, both simple and long ones. For each vowel, but only four of them are taken into account here as the researchers believed that four words were enough to represent each monophthong, also because some words contained a diphthong, which was not the focus of our investigation. All the words were mixed in a way that the participants could not determine what was being highlighted when they were reading the words. If we had grouped all the words based on the vowel they shared, it would be more likely that the participants would feel that their pronunciation of a particular vowel sound was being evaluated and thus they would constantly self-correct their pronunciation and try to give self-conscious responses. All the results of this study are based on the pronunciation of forty-eight words, rather than sixty.

\subsection{Participants}

The participants (male and female) of this study were twenty undergraduate EFL learners from the English Department, School of Languages, University of Zakho, during the 20162017 academic year. Ten of them were in the third grade and the other ten in the fourth grade. From each grade, five males and females were selected. They were homogenous in their English language schooling background. That is, by the time they were used as samples, all of them had studied English for a minimum of eight to nine years. Learners who had lived abroad for some time were not included as samples because the difference in their exposure to and education of English would certainly affect their pronunciation of the English words. There were also students whose first language was not Kurdish, but either Arabic or Aramaic. Those were not included in the samples either.

\subsection{Tools and Procedures}

In this study, the researchers depended on tape recordings to collect data. For recording participants' readings of a sixtyword wordlist, the voice recording tool of a Samsung Galaxy S6 smartphone was used. This tool was used because it had perfect sound quality in terms of clarity and audibility.

Recording of participants' voices took place in the last week of March 2017 in a quiet room of the Department of English at University of Zakho. All recordings were not run in one day, but over the span of one week because at that time students were attending their classes and tending to their coursework and term exams. They were called in during their free time when they did not have any engagements. Participants were taken one at a time without any other participants in the room at the time of recording. To maintain authenticity and reliability, they were not informed about the exact purpose of their reading of the words (pronunciation of vowels), but were told that their reading was to be used for research purposes. They were also told that they did not need to worry about making mistakes when reading the words because their recorded voices would be anonymous and that there were no right or wrong readings. Each participant was given a numbered sheet of the wordlist and was given chance to have a look at the words first before the recording started. In total, twenty-five recordings were carried out of which only twenty were used for data analysis because we wanted to make sure we would get the number of recordings that we had aimed for, which was 20 . Besides, two participants jumped over a whole column of words in the list and therefore, were ruled out. Each recording took about one minute and forty seconds.

The recordings were then listened to and phonetically transcribed by the researchers. Correct pronunciations and mispronunciations were all transcribed and the data were analyzed using both qualitative and quantitative methods. On the one hand, we focused on how participants pronounced English monophthong vowels and how many of them pronounced a certain vowel or set of vowels in a certain way, while on the other.

\section{Results}

The results are arranged in percentages and are classified according to their realizations of the monophthongs produced by the participants. The recordings of the wordlist containing all the twelve monophthongs come from both EFL third- and fourth-year students of the Department of English at University of Zakho during the 2015 - 2016 academic year. In this study, primary focus is on how these learners as a whole pronounce English monophthongs as both groups of participants have studied English phonetics and phonology during the second year of their undergraduate study. All the twelve vowel sounds were mispronounced by the participants with varying degrees. One general basic reason for mispronounced cases is changing the vowel quality (Ladefoged, 1993: 79-80). In other words, vowels may be pronounced differently due to the fact that some vowels show approximate qualities. According to Abercrombie (1967: 91), the quality of the sound refers to "those characteristics which are present more or less all the time that a person is talking". When producing any sound, especially vowels, whispers, sighs, coughs and throat clearing are taken into consideration. The following chart displays the variance between monophthongs and their mispronunciation:

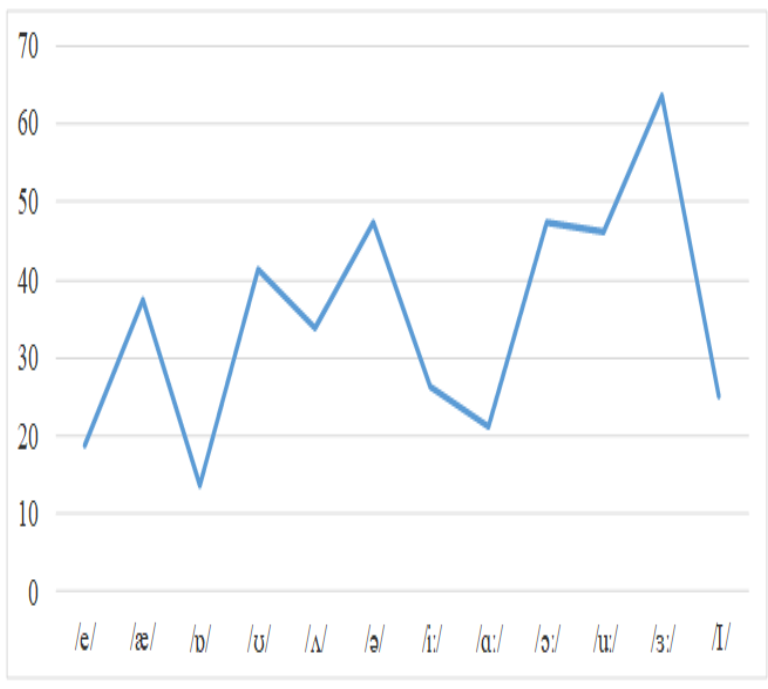

Figure 2: Percentages of Mispronunciation of Monophthongs At the time of recording participants' pronunciation of the words, they were not informed about the exact purpose of their reading of the wordlist. Instead, they were told that the data were to be used for academic and research purposes and that there were no right or wrong answers. They were also told that their responses would be anonymous. Therefore, they did not need to feel nervous or worry about any mistakes they might make when reading the words. The researchers did this so that when reading the words, they would not correct themselves and become self-conscious as that would render the results artificial and unauthentic. It is worth noting that evaluation of participants' pronunciation of monophthongs is based on the Received Pronunciation (RP), which is the Standard English pronunciation in the United Kingdom. This is due to the fact that in Iraqi Kurdistan's education system, English pronunciation is taught mostly according to RP. As manifested in Appendix II, the results of our study are reported in the following sub-sections.

\subsection{The High Front Vowels $/ \mathbf{1} /$, /i:/ and /e/}

In general, this group of vowels received a relatively low percentage of mispronunciations by the participants. The short 
/I/ vowel, for example, recorded $25 \%$ of wrong pronunciations amounting to twenty out of eighty cases altogether. About a quarter, that is, $21.25 \%$ of the participants pronounced this vowel as [e], 2.5\% pronounced it as [i:] and $1.25 \%$ pronounced it as [aI] - it was pronounced like this in the word bit in one case only. The long high front vowel, /i:/, on the other hand, recorded the highest percentage of mispronunciation (26.25\%) in this group. Hence, $16.25 \%$ realized it as [e] and $10 \%$ of them realized it as [I]. The last sound from this group, /e/ was mispronounced by $18.75 \%$ of the participants. $5 \%$ of them gave it the $[\mathrm{eI}]$ representation, while it was realized as [I] by $7.5 \%$ and as [i:] by $6.25 \%$ respectively.

\subsection{The Vowels /a/ and /a:/}

These vowels recorded a higher percentage of mispronunciations by the participants than the high front vowels. The /æ/ vowel was mispronounced by $37.5 \%$ of the participants and /a:/ received $21.25 \%$ of mispronunciations. The latter was realized as [p] by $2.5 \%,[\Lambda]$ by $3.75 \%$, [æ] by $11.25 \%$, [o: $]$ by $2.5 \%$, and [əo] by $1.25 \%$, while the former was realized as [ə] by $2.5 \%$, [eI] by $3.75 \%$, [ $\Lambda$ ] by $20 \%$, [a:] by $8.75 \%$, and [e] by $2.5 \%$, respectively.

\subsection{The High Vowels / $/ \mathbf{p}$ and / $/$ :/}

These vowels received a percentage of mispronunciations that was perceptibly higher than the one that high front vowels /I/ and $/ \mathrm{i}: /$ received. The first sound, /p/ was mispronounced by $13.75 \%$ of the participants, but nearly half of them, that is, $47.5 \%$ mispronounced the long / $\mathrm{s}$ / / vowel sound. Thus, if we compare percentages of both high front and these two back vowels, we will see that the latter were mispronounced more often than the former pair of vowel sounds. In other words, $/ \mathrm{p} /$ and $/ \mathrm{s}: /$ together had $61.25 \%$ of the mispronunciations, but $/ \mathrm{I} /$ and /i:/ had $51.25 \%$ of the mispronunciations in total. The vowel $/ \mathrm{p} /$ was realized as [ə] by $6.25 \%$, as [u] by $1.25 \%$, as [u:] by $7.5 \%$, as $[\Lambda]$ by $2.5 \%$, and as [a:] by $3.75 \%$. Similarly, but not identically, the $/ \mathrm{o}: /$ sound was realized as $/ \partial 0 /$ by $20 \%$, as [av] by $6 \%$, as $/ \mathrm{p} /$ by $8.75 \%$, [ $\Lambda$ ] by $3.75 \%$, /a:/ by $3.75 \%$, and [u:] by $5 \%$.

\subsection{The High Back Vowels /o/ and /u:/}

These vowels recorded a significantly higher percentage of mispronunciations than the high from vowels. The short sound $/ \mho /$, for instance, was mispronounced by $41.25 \%$ of the participants while the long vowel /u:/ was mispronounced by $46.25 \%$ of the participants. This percentage of participants

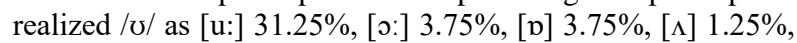
and $[\mathrm{u}] 1.25 \%$. The other one, that is, $/ \mathrm{u}: /$, was realized as $[\mathrm{v}]$ by $8.75 \%$, [०:] by $2.5 \%$, [əo] by $10 \%$, [p] by $16.25 \%,[\Lambda]$ by $5 \%$, [a:] by $2.5 \%$, and [u] by $1.25 \%$. Thus, $/ \mho /$ was pronounced mostly as [u:] and /u:/ was pronounced mostly as [p] followed by $[ə \mho]$ and $[\mho]$.

\subsection{The Central Vowels / $/ /, / 3: /$ and /a/}

These vowels were mispronounced the most among all the vowels included in the wordlist. Most of the participants failed to pronounce each one of these central vowels correctly; $63.75 \%$ of them mispronounced $13: /, 47.5 \%$ of them mispronounced $/ \mathrm{a} / \mathrm{a}$ an $33.75 \%$ of them mispronounced $/ \mathrm{L} /$. The long central /3:/, which received the highest percentage of mispronunciation, was realized mostly as [e] by $28.75 \%$, [o: by $22.5 \%$ and [u:] by $11.25 \%$. Only once, that is, by $1.25 \%$ was this sound pronounced as $[\Lambda]$ where the word burn /b3:n/ became [b $\wedge \mathrm{rn}]$. Other realizations of this vowel were manifested in the word certain becoming [setən, sertən and serteIn], work becoming [wo:k, wo:rk, wu:k, wu:rk and work], worse becoming [wo:s, wo:rs, wu:s, wu:rs and werəs] and burn becoming [ben, bern, bo:rn, born, and bsrn]. The central vowel that had the second highest percentage of mispronunciation from this group was $/ \partial /$, the schwa. It was realized as [æ] by
$38.75 \%$ of the participants in the words ago and away, while it was realized as [a:] by $8.75 \%$ in the word tenant.

\section{Discussion}

The data of the study suggest that there is clear mispronunciation of monophthong vowels by EFL learners in NK with varying degrees. This problem with English vowels is because of two main reasons: first, the phonetic system of NK is different from that of English, and second, the orthography of NK is different from that of English. In other words, in NK, sounds are pronounced based on how they are written, that is, their form. Such a type of mispronunciation leads to problems in communication. Hence, the better the pronunciation of sounds, the better the communication is. This is what Mirzaei, et al (2015: 387) claim, stating that "correct pronunciation makes our speech understandable and comprehensible to our interlocutors". The data are discussed in the following subsections.

\subsection{The $/ \mathbf{I} /, / \mathbf{i} /$ and $/ \mathrm{e} /$ vowels}

As can be seen from Figure (2) above, the /I/, /i:/ and /e/ monophthongs have lower percentages of mispronunciation compared to the rest of the vowels. These three monophthongs were mispronounced by $29.1 \%$ of the participants. The /I/ vowel is mispronounced by the participants and most of them realized it as [e] as in the word built, bit, deploy and exam. In fact, this replacement of /I/ with /e/ does not happen randomly; rather, it happens because in the orthography of NK, the /I/ sound does not have a symbol; that is, it is pronounced but not written. For instance, in NK the word (هزر) [hIzIr], meaning (idea, thought), /I/ is not represented orthographically by any symbol and this is where the sound occurs between two consonants. This is due to the Perso-Arabic script adopted in Iraqi Kurdistan Region. Arguably, it seems understandable that Kurdish EFL learners substitute this vowel with an easier one because the original one does not occupy any place in the spelling of their mother tongue. This sound was also realized as both [i:] twice and as [ar] just once for the same reasons mentioned above.

The /i:/ vowel has $26.25 \%$ of mispronunciations which has both [e] and [I] representations in the results. Words representing this sound were tea, weep, heat, and peel. On the one hand, it seems strange that this percentage of participants, who are junior and senior, pronounce it as /e/. The fact is, orthography plays a major role here; when the NK learner sees the letter "e" he/she treats it as the phonetic/e/ sound rather than a letter that may not always represent such a sound. One can say that when reading English words which contain the /e/ vowel, the NK learners think as if they are imposing the phonetic system of their first language on a foreign language that they learn about. The last vowel from this group, /e/ is the second least mispronounced sound by the participants with just $18.75 \%$. According to the results, it has [eI], [I] and [i:] realizations with similar percentages. Examples in which this sound appears are said, member, fed and blend. Mistaking /e/ for [eI] is somehow plausible because of its orthography, but pronouncing it as [I] or [i:] is not justifiable. Hence, it becomes obvious that in cases like this one, they key factor for this is learners' lack of practice in English pronunciation.

\subsection{The /ae/ and /a:/vowels}

Concerning these two low monophthongs, no significant difference is recorded for them. The overall percentage of mispronunciation is $29.5 \%$. The first one, /æ/, is pronounced mostly as $/ \mathrm{N} /$ in the words jacket and family. This is due to the difficulty of pronouncing the /æ/ vowel as very flat and neutral in NK. Instead, NK uses a similar sound to substitute /æ/ and that sound shares the same phonological features except that it is a little shorter in duration than the English one. This NK 
sound is sometimes symbolized as [ă]. However, this sound is treated as equal to the English /æ/ in this study. Thus, Kurdish

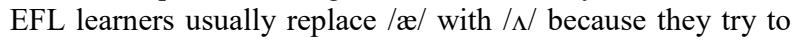
make it shorter to adapt it to the phonetic system of their first language. In this regard, Flege (1995: 233) suggests that learners will produce new sounds in L2 to create phonetic categories that have no equivalents in L1. The same is true of the English /a:/, that is, it does not exist in NK. There is a similar sound to /a:/ in NK but it is a little shorter in duration. This /a:/ vowel is mispronounced by $21.25 \%$ and it is mostly replaced by [æ] in the words such as half, laugh, draft, and last. The reason for this is that learners try to make it shorter.

\subsection{The $/ \mathbf{p} /$ and $/ \mathbf{s}$ :/ vowels}

From all the vowels in the list $/ \mathrm{p} /$ is the least mispronounced sound with just $13.75 \%$ and $/ 5: /$ is the second most mispronounced sound after central /3:/; it has $47.5 \%$ of wrong pronunciations. This is the reason that Kurdish EFL learners replace $/ \mathrm{s} / /$ with other sounds, namely, [əv] and [av] in caught and law. In both words, the spelling is not straightforward to the foreign reader. In other words, an NK reader is more likely to pronounce law /1b:/ as [lav] and [ləo]. Simply, this is due to the orthography of their first language: لاو and whose transcriptions are $/ \mathrm{lao} /$ and $/ \mathrm{lu}(:) /$ respectively. As for pronouncing caught $/ \mathrm{ks}: \mathrm{t} /$, they pronounce it as [kəot] and [kavt]. One can argue that this happens because in NK this word is written as either كووت and كاوت which can be transcribed as /ku:t, kəot/ and /kavt/. Another possible factor is that Kurdish learners confuse law with low and caught with coat when they read them. They do not practice English pronunciation enough to distinguish them from each other.

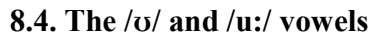

This pair of high back monophthongs are the second most widely mispronounced vowels among the others with a total percentage of $43.75 \%$. Although these vowels are familiar to the participants because they are present in their language, they still mispronounce them to a good extent. In most cases, $/ \mho /$ is pronounced as [u:], that is, by $31.2 \%$ (25 times) as in the words foot, pull, push and full altogether. Participants tend to lengthen $/ \mho /$ because its use is less widespread than /u:/ in the NK. This signifies that the latter is a lot more commonly found in NK words than the former which is why they tend pronounce it like that. In NK, / / / is found in very few words, such as in /kutlk/ (name of a traditional meal), كوله /kolæ/ (mosquito net),

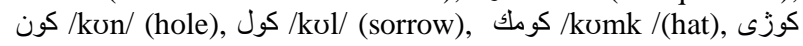
/kuzi:/ (corner), قون الع/qula:ty/ (nook, corner) and قوك /quta:n/ (hitting). As for /u:/, it is mostly pronounced as [p], especially in the word lose which, in most cases, has been pronounced as [los] rather than as /lu:z/. This sound is also replaced by /ov/ quite often in the words flute and soup giving them both [floot] and [səop] pronunciations. While it seems reasonable to use $/ \mho /$ and /u:/ interchangeably, it is surprising that participants use mostly / $\mathfrak{w} /$ in place of /u:/ because as mentioned earlier, $/ \mathfrak{w} /$ is not very widespread on the phonetic map of Kurdish language. Many foreign learners of English believe that English pronunciation is crazy whereby words such as soup and soap that are close in both spelling and sound can be easily confused. Another reason could be insufficient or lack of exposure to English pronunciation input. While it is true that participants of this study have studied English phonetics in a formal setting, university, it is highly unlikely that without extracurricular and outside class practice they will master English pronunciation quite well.

\subsection{The /ə/, /3:/ and / $/$ / vowels}

These central vowels constitute the greatest challenge for the Kurdish EFL learners as they are mispronounced more than all the other monophthongs in the wordlist. Together, they make up $43.3 \%$ of the mispronunciations, with $/ 3: /$ being mispronounced by $63.7 \%$, which is the highest percentage amongst the results. The schwa vowel, /a/, is the second most mispronounced sound with $47.5 \%$, while $/ \mathrm{N} /$ is the least mispronounced of central vowels with $33.7 \%$. As can be seen in in the results, /3:/ is pronounced mostly as [e] in the word certain, as [o:] and [u:] in the words work and worse. Participants' motif for reading certain /s3:tn/ as [se(r)tən] is mostly because of the influence of the orthography of their first language which pronounces words and letters based on their form. Hence, the letter " $\mathrm{e}$ " in certain is more likely to be read as [e] than any other sound because they are similar in form, let alone as a sound that has no place in the phonetic system of their mother tongue. Similarly, $/ 3: /$ is pronounced also as [0:] in work and worse because of the shape of the letter "o" in the words. Thus, work /w3:k/ becomes [wo:k] and worse /w3:s/ becomes [wo:s] quite frequently. The same sound, that is, $/ 3: /$, is also very often pronounced as [u:] in the words work and worse for the very same L1 orthographical reasons. The words are thus read as [wu:(r)k] and [wu:(r)s]. The letter "o" is only once $(1.2 \%)$ and it is realized as [p] and that is in the word work. This proves the argument that $/ \mathrm{p} /$, though present in the sound system of $\mathrm{NK}$, is actually very rarely pronounced by its speakers.

The schwa, /ə/, on the other hand, is pronounced mostly as [æ] in the words ago and away, by $38.7 \%$. Once again, phonetics of Kurdish language, which relies heavily on the shape of letters encourages Kurdish EFL learners to read the letter "a" in ago and away as [æ]. They do this because /ə/ does not have an orthographic symbol in their language. This is what O'Connor (1980: 83) focused on, stating that the pronunciation of this very short vowel has two main difficulties: (1) how to identify it and (2) how to get the right quality. This sound is also pronounced as [a:], especially in the word tenant/tenənt/, but to a much lesser extent, $(8.7 \%)$.

Finally, $/ \Lambda /$ is pronounced mostly as $[\mathrm{p}]$ in the word glove and as [æ] in the word luck. In this way, glove $/ \mathrm{gl} \Lambda \mathrm{v} /$ is read as [glpv] and luck / $1 \Lambda \mathrm{k} /$ as [læk] by the participants. In one sense, pronouncing " $\mathrm{o}$ " in glove as [p] is understandable because both look similar in spelling, however, pronouncing " $u$ " in luck as $[\mathfrak{~}]$ is a little less credible. These two do not share similar forms, so one only wonders why they should be confused by the readers. In this context, the best explanation is that Kurdish EFL learners pronounce the letter " $u$ " as $[æ]$ rather than $[v],[u]$ or [u:] in the word luck because the word is used and heard very regularly both orally and in writing in various everyday life situations and is often mispronounced by non-native speakers of English world-wide. In the NK media, the English word luck in particular is most often pronounced as [læk].

\section{Conclusion}

This study explored and investigated Kurdish EFL learners' problems with English monophthong vowels. Worth noting is that in this study the assessment and evaluation of participants' pronunciation of English monophthongs is done according to the RP (Received Pronunciation) accent of English, which is the standard accent of British English. The main points of conclusion are the following:

1. The central vowels are the most problematic sounds for Kurdish EFL learners in terms of pronunciation followed by high back vowels. Results indicate that NK learners struggle with central English vowels, /a, 3:, and $\Lambda /$. This is mainly due to their absence in the phonetic system of their first language, Kurdish. Therefore, whenever they encounter these sounds in English words, they usually replace them with sounds that are already present in Kurdish. These replacements are as follows: $/ \mathrm{/} /$ is realized mostly as [æ], /3:/ as [e], [o:] and [u:] depending on which letter represents the sound in the English word. That is, if the sound in perspective is represented by "a" as in ago and away, usually it will be pronounced as [æ] by Kurdish EFL 
learners; if it is represented by "e" as in certain, usually it will be pronounced as [e]; and if the sound is represented by "o" as in work and worse, usually it will be pronounced either as [o:] or [u:]. This indicates that the main reason Kurdish EFL learners mispronounce English vowels in general is the influence of the phonetics and orthography of their own language in which words and letters are pronounced depending on their physical form. The other main factor is because certain English vowels, namely, /a, 3:, and $\Lambda /$ do not exist in the phonetic system of Kurdish language.

2. The high back vowels, / $/$ and /u:/ come in the second rank in being challenging for the Kurdish EFL learner to produce. The sound / $/$ / is replaced mostly by /u:/ because it is less commonly found in NK. It is also observed that mid front, low front (except /æ/), mid back and low back vowels are the least problematic sounds for Kurdish EFL learners to pronounce compared to central and high back vowels. Finally, while it was expected that participants would have the biggest problem with central vowels, which are absent in their L1, results show that they the high back vowels / $/$ and /u:/ also are considerably challenging for them, despite the fact that these two sounds are present in their L1. Kurdish EFL learners' lack of exposure to sufficient English pronunciation or listening input also may have played an essential role in their struggle with English monophthong vowels because none of the vowels escaped wrong pronunciation. This is embarrassing for the instruction of English at university level because based on these results, it could be argued that (1) pronunciation is not given adequate attention in the curriculum and or (2) generally, Kurdish EFL students do not exert adequate efforts into learning and practicing the English vowels. It is also implicated that (3) sometimes even Kurdish EFL teachers have poor English pronunciation which has adverse effects on Kurdish EFL learners' competence in the pronunciation of the target language (English).

\section{References}

Abercrombie, David (1967). Elements of General Phonetics. UK: Edinburgh University Press.

Ali, E. M. T. (2013). Pronunciation problems: Acoustic analysis of the English vowels produced by Sudanese learners of English. International Journal of English and Literature, 4(10), 495-507.

Flege, J. E. (1995). "Second Language Speech Learning: Theory, Findings, and Problems". In Winfred Strange (Ed.),
Speech Perception and Linguistic Experience: Issues in CrossLanguage Research. Timonium, MD: York Press. Pp. 233-277. Hago, O. E. and Khan, W. A. (2015). "The Pronunciation Problems Faced by Saudi EFL Learners at Secondary Schools." [Online] Education and Linguistics Research, 1 (2), pp. 85-99. Retrieved June 12, 2019 from http://www.macrothink.org/journal/index.php/elr/article/down load/7783/6813.

Hassan, E. M. Idris (2014). "Pronunciation Problems: A Case Study of English Language Students at Sudan University of Science and Technology." [Online] English Language and Literature Studies, 4 (4), pp. 31-44. Retrieved June 2, 2019 from

https://pdfs.semanticscholar.org/c23e/60a601e5db8a46deb668 f6d92f2e5a4e2ffe.pdf/

Ladefoged, Peter (1993). A Course in Phonetics. $3^{\text {rd }}$ Ed. New York: Harcourt Brace.

Ma, Lin (1997). "English Learning: An Analysis of Chinese Students' Problems in Pronunciation". [Online] ERIC, 143, pp. 1-31. Retrieved July 3, 2019 from https://files.eric.ed.gov/fulltext/ED411668.pdf.

Matsubara, J. (2015). An emerging area in second language phonology: the perception of English vowels by adult second language learners. Teachers College, Columbia University Working Papers in TESOL \& Applied Linguistics, 6(2), $\begin{array}{llll}\text { Retrieved July } & 2, & 2019 & \text { from }\end{array}$ http://www.tc.columbia.edu/tesolalwebjournal .

Mirzaei, K, Gowhary, H., Azizifar, F. and Esmaeili, Z. (2015). "Comparing the phonological performance of Kurdish and Persian EFL learners in pronunciation of English vowels." [Online] Procedia, 199, pp. 387-393. Retrieved June 27, 2019 from https://cyberleninka.org/article/n/1392296.pdf/ .

Munro, JM. (1993). Productions of English vowels by native speakers of Arabic: Acoustic Measurement and Accentedness Ratings. Lang. Speech 36:39-61.

O'Connor, J. D. (1980). Better English Pronunciation (2nd ed.). Cambridge: Cambridge University Press.

Roach, Peter. (2000). English Phonetics and Phonology: A Practical Course. $3^{\text {rd }}$ ed. Cambridge: Cambridge University Press.

Yule, George (2006). The Study of Language. Cambridge: Cambridge University Press.

Zhang, F. and Yin, P. (2009). "A Study of Pronunciation Problems of English Learners in China." [Online] Asian Social Science, 5 (6), pp. 141-146. Retrieved June 2, 2019 from https://pdfs.semanticscholar.org/4732/7dad6066a0a6aa1e37a8 3b5ac8a5d236a583.pdf. 


\section{Appendix I: Wordlist Containing all the English Monophthongs}

Dear participant,

Please kindly read the following words clearly, one at a time.

\begin{tabular}{|c|c|c|c|c|c|}
\hline $\begin{array}{l}\text { Gende } \\
\text { Grade }\end{array}$ & $\begin{array}{c}\text { Male } \square \\
\text { Third } \square\end{array}$ & $\begin{array}{l}\text { Female } \\
\text { Fourth } \square\end{array}$ & & & \\
\hline 1. & Snack & 21. & Worse & 41. & hand \\
\hline 2. & Built & 22. & Borrow & 42. & certain \\
\hline 3. & Deploy & 23. & pot & 43. & fed \\
\hline 4. & collapse & 24. & draft & 44. & soup \\
\hline 5. & exam & 25. & food & 45. & last \\
\hline 6. & bit & 26. & family & 46. & tea \\
\hline 7. & said & 27. & push & 47. & flute \\
\hline 8. & wonder & 28. & luck & 48. & weep \\
\hline 9. & nose & 29. & attach & 49. & pile \\
\hline 10. & member & 30. & full & 50. & heat \\
\hline 11. & jacket & 31. & law & 51. & pull \\
\hline 12. & glove & 32. & tenant & 52. & corn \\
\hline 13. & structure & 33. & ago & 53. & sitting \\
\hline 14. & laugh & 34. & today & 54. & gossip \\
\hline 15. & foot & 35. & lose & 55. & work \\
\hline 16. & money & 36. & away & 56. & null \\
\hline 17. & college & 37. & forge & 57. & caught \\
\hline 18. & superb & 38. & stick & 58. & east \\
\hline 19. & peel & 39. & half & 59. & pool \\
\hline 20. & complex & 40. & blend & 60. & burn \\
\hline
\end{tabular}

Appendix II: Pronunciation of English Monophthongs by the Participants

\begin{tabular}{|c|c|c|c|c|c|c|c|c|c|c|}
\hline /e/ & S1 & S2 & S3 & S4 & S5 & S6 & S7 & S8 & S9 & $\mathrm{S} 10$ \\
\hline said & sed & sed & sed & sed & sed & Sed & sed & sed & sed & seId \\
\hline member & mi:mbə & membə & membə & membə & membə & membə & membə & membo & membə & membə \\
\hline fed & fed & fid & fed & fed & fid & Fed & fi:d & fid & fed & fed \\
\hline blend & blend & blend & blend & blend & blend & Blend & blend & blend & blend & blend \\
\hline$/ \mathrm{e} /$ & S11 & S12 & S13 & S14 & S15 & S16 & S17 & S18 & S19 & S20 \\
\hline said & sed & sed & set & seid & sed & Sed & seId & sed & sed & seId \\
\hline member & mi:mbə & membə & membə & membə & membə & membə & membə & membə & membə & membə \\
\hline fed & fi:d & fed & fet & fed & fed & fid & fi:d & fid & fed & fed \\
\hline blend & blend & blend & blend & blind & blend & blend & blend & blend & blend & blend \\
\hline$/ \mathbf{I} /$ & S1 & S2 & S3 & S4 & S5 & S6 & S7 & S8 & S9 & S10 \\
\hline built & bilt & bilt & bilt & bilt & bilt & bilt & Belt & bilt & bilt & bilt \\
\hline deploy & depləı & diploI & diploI & diploI & diploI & diploı & diploI & diploI & diploI & diploI \\
\hline exam & ekzæm & Ikza:m & Igzæm & Igzæm & ekza:m & Ikza:m & ekza:m & ekzæm & Igzæm & Igzæm \\
\hline bit & bet & bi:t & Bet & bit & bit & bit & Bet & bit & bit & bi:t \\
\hline$/ \mathbf{I} /$ & S11 & S12 & S13 & S14 & S15 & S16 & S17 & S18 & S19 & S20 \\
\hline built & bilt & bilt & bilt & bilt & belt & bilt & Belt & bilt & bilt & bilt \\
\hline deploy & diploI & diploI & diplor & diploI & diploI & diploı & diploI & diploI & diploI & diploI \\
\hline exam & Igzæm & Igzæm & ekza:m & Ikzæm & ekzæm & ekzæm & Ikza:m & Igzæm & ekza:m & Igzæm \\
\hline bit & bit & bet & bit & bit & bait & bit & Bet & bit & bit & bit \\
\hline$/ \mathfrak{a} /$ & S1 & $\mathrm{S} 2$ & S3 & S4 & S5 & S6 & S7 & S8 & S9 & S10 \\
\hline collapse & kəlæps & kpləps & kəlæps & kəlæps & kəlæps & kəlæps & kpleıps & kəla:ps & kəlæps & kəlæps \\
\hline jacket & dzækit & dzskit & dzsket & dzækit & t $\Lambda$ ket & dza:ket & des ket & dza:ket & dzæket & ḑsket \\
\hline
\end{tabular}




\begin{tabular}{|c|c|c|c|c|c|c|c|c|c|c|}
\hline snack & snæk & snæk & Snæk & snæk & $\operatorname{sn} \Lambda \mathrm{k}$ & snæk & Snek & snæk & snæk & snæk \\
\hline family & fæməli & fæməli & fæməli & fæməli & f $\wedge$ məli & fæməli & f $\wedge \mathrm{mli}$ & femli & fæməli & f $\wedge \mathrm{mli}$ \\
\hline$/ \mathfrak{a} /$ & S11 & S12 & S13 & S14 & S15 & S16 & S17 & S18 & S19 & S20 \\
\hline collapse & kəlæps & kpləps & kəlæps & kəlæps & kolæps & kəlæps & kolæps & kəlæps & kolæps & kəlæps \\
\hline jacket & dzæket & dz $\Lambda$ ket & dz^ket & dgæket & dz $\Lambda$ ket & dz^ket & dzæket & dzæket & dgsket & dzækIt \\
\hline snack & sna:k & snæk & snæk & snerk & sənæk & sna:k & sna:k & snæk & snerk & snæk \\
\hline family & fæmli & fæmli & fæməli & fæməli & f $\wedge$ məli & f $\wedge$ məli & fa:mli & fæməli & fæməli & fæməli \\
\hline$/ \mathbf{p} /$ & S1 & S2 & S3 & S4 & S5 & S6 & S7 & S8 & S9 & S10 \\
\hline complex & kəmpleks & kəmpleks & kpmpleks & kpmpleks & kpmpleks & kpmpleks & kpmpleks & kpmpleks & kpmpleks & kbmpleks \\
\hline gonssip & $\mathrm{g}_{\Lambda \mathrm{sip}}$ & gozip & gpsip & gpsip & gosp & gpsip & gu:sp & gpsip & gpsip & gosip \\
\hline borrow & bprəu & bərəo & bprəu & b $\Lambda$ rəo & bors: & bprəu & bprəu & bprəu & bpro & bprəu \\
\hline pot & ppt & ppt & $\mathrm{ppt}$ & $\mathrm{ppt}$ & ppt & ppt & $\mathrm{ppt}$ & ppt & $\mathrm{ppt}$ & $\mathrm{ppt}$ \\
\hline$/ \mathbf{p} /$ & S11 & S12 & S13 & S14 & S15 & S16 & S17 & S18 & S19 & S20 \\
\hline complex & kpmpleks & kbmpleks & kəmpleks & kpmpleks & kbmpleks & kpmpleks & kbmpleks & kbmpleks & kompleks & kbmpleks \\
\hline gossip & gosip & gpsip & gosp & gu:sip & gpsp & gpsip & gusip & gpsip & gpsip & gpsip \\
\hline borrow & bprəv & bprəo & bprəv & bprəu & boro & boru: & bəro: & bprəv & bprəv & bprəv \\
\hline pot & ppt & ppt & ppt & ppt & ppt & ppt & ppt & ppt & ppt & ppt \\
\hline$/ 0 /$ & S1 & S2 & S3 & S4 & S5 & S6 & S7 & S8 & S9 & S10 \\
\hline foot & fout & fơt & fu:t & fout & fơt & fu:t & fu:t & fu:t & fu:t & fu:t \\
\hline pull & pol & pol & pu:1 & pol & pol & pu:1 & pol & pol & pol & pol \\
\hline push & pos & $\mathrm{pp} \int$ & pos & pos & $\mathrm{p} \Lambda \int$ & pu: $\int$ & pos & $\mathrm{pu}: \int$ & pos & pos \\
\hline full & fol & fol & fu:1 & ful & fol & fo: 1 & fol & fol & fo: 1 & fol \\
\hline$/ \mho /$ & S11 & S12 & S13 & S14 & S15 & S16 & S17 & S18 & S19 & S20 \\
\hline foot & fu:t & fu:t & fu:t & fu:t & fu:t & fu:t & fu:t & fu:t & fu:t & fơt \\
\hline pull & pu:1 & pol & pol & pol & ppl & pu:1 & ppl & pol & pol & pol \\
\hline push & pos & pos & pos & pos & pos & pos & pos & pos & pos & p $v \int$ \\
\hline full & fu:1 & fơl & foll & fol & fo: 1 & $\mathrm{fu}: 1$ & fu:1 & fol & fol & forl \\
\hline$|\mathbf{A}|$ & S1 & S2 & S3 & S4 & S5 & S6 & S7 & S8 & S9 & S10 \\
\hline glove & $\mathrm{gl} \Lambda \mathrm{v}$ & gləuv & $\mathrm{gl} \Lambda \mathrm{v}$ & glu:v & glpf & glo:v & glpv & glpv & $\mathrm{gl} \Lambda \mathrm{v}$ & glpv \\
\hline structure & struktfə & strıktfə & str $\Lambda \mathrm{ktf \partial}$ & struktfə & $\operatorname{str} \Lambda \mathrm{ktj} \partial$ & $\operatorname{str} \Lambda \mathrm{ktj} \partial$ & strıktəa & str $\Delta k t \jmath \partial$ & struktfo & strıktəo \\
\hline luck & læk & $1 \wedge \mathrm{k}$ & $1 \wedge \mathrm{k}$ & $1 \Lambda \mathrm{k}$ & $1 \wedge \mathrm{k}$ & la:k & $1 \wedge \mathrm{k}$ & la:k & $1 \wedge \mathrm{k}$ & $1 \wedge \mathrm{k}$ \\
\hline money & mıni & mıni & mıni & mıni & mıni & mıni & mıni & m^ni & mıni & mıni \\
\hline$|\mathbf{A}|$ & S11 & S12 & S13 & S14 & S15 & S16 & S17 & S18 & S19 & S20 \\
\hline glove & glpv & klpv & glıv & glauv & gəlu:v & glpv & glpv & $g l_{\Lambda \mathrm{v}}$ & $\mathrm{gl} \Lambda \mathrm{v}$ & glpv \\
\hline structure & sətræktjo & str $\Lambda \mathrm{ktj}$ & sətr $\Delta \mathrm{ktf \partial}$ & $\operatorname{str} \Lambda \mathrm{ktf} \partial \mathrm{r}$ & sətr $\Lambda \mathrm{kt} ə$ & $\operatorname{str} \Delta \mathrm{ktj} \partial$ & stræktjə & str $\Lambda \mathrm{ktj}$ & $\operatorname{str} \Lambda \mathrm{ktj} \partial$ & $\operatorname{str} \Lambda k t \jmath \partial$ \\
\hline luck & $1 \wedge k$ & lok & $1 \wedge \mathrm{k}$ & læk & læk & læk & la:k & $1 \wedge \mathrm{k}$ & læk & læk \\
\hline money & mıni & mıni & m^ni & mıni & mıni & mıni & mæni & mıni & mıni & $\mathrm{m} \wedge \mathrm{ni}$ \\
\hline /o/ & S1 & S2 & S3 & S4 & S5 & S6 & S7 & S8 & S9 & S10 \\
\hline tenant & tenont & tena:nt & tena:nt & tenont & tina:nt & tena:nt & ti:na:nt & ti:nənt & tenənt & tenənt \\
\hline ago & ægəu & әgəu & ægo: & ægəu & ægu: & əgəठ & ægu: & әgəu & əgəu & əgəひ \\
\hline today & tədeI & todeI & tədeI & tədeI & todeI & tədeI & tədeI & todeI & tədeI & tədeI \\
\hline away & æweI & әweI & æweI & æweI & æweI & әweI & æweI & әweI & æweI & әweI \\
\hline /ə/ & S11 & $\mathrm{S} 12$ & S13 & S14 & $\mathrm{S} 15$ & S16 & S17 & $\mathrm{S} 18$ & S19 & $\mathrm{S} 20$ \\
\hline tenant & tenænt & ti:nənt & ti:nənt & tenənt & tena:nt & tenənt & tena:nt & tenənt & tenənt & tenənt \\
\hline ago & ægəひ & ægəひ & əgəu & ægəひ & ægəठ & ægəひ & ægu: & ægəひ & ægəひ & ægu: \\
\hline today & tədeI & tədeI & todeI & tədeI & todeI & tədeI & tədeI & todeI & tədeI & tədeI \\
\hline away & æweI & æweI & æweI & æweI & æweI & æweI & æweI & æweI & æweI & æweI \\
\hline$/ \mathbf{i}: /$ & S1 & $\mathrm{S} 2$ & S3 & S4 & S5 & S6 & S7 & S8 & S9 & $\mathrm{S} 10$ \\
\hline tea & ti: & ti: & ti: & ti: & ti: & ti: & ti: & ti: & ti: & ti: \\
\hline weep & wi:p & wep & wi:p & wi:p & wi:p & wi:p & wep & wIp & wi:p & wi:p \\
\hline
\end{tabular}




\begin{tabular}{|c|c|c|c|c|c|c|c|c|c|c|}
\hline heat & hi:t & hi:t & hi:t & hi:t & het & het & Het & hi:t & hi:t & het \\
\hline peel & pi:1 & pi:1 & pi:1 & pi:1 & pil & pil & pi:1 & pi:1 & pi:1 & pi:1 \\
\hline$/ \mathbf{i}: /$ & S11 & $\mathrm{S} 12$ & S13 & S14 & S15 & S16 & S17 & S18 & S19 & S20 \\
\hline tea & ti: & ti: & ti: & ti: & ti: & ti: & ti: & ti: & ti: & ti: \\
\hline weep & wIp & wip & Wep & wi:p & wi:p & wip & Wep & wep & wi:p & wi:p \\
\hline heat & het & hi:t & hi:t & hi:t & hi:t & hit & Het & hi:t & hi:t & hi:t \\
\hline peel & pi:1 & pi:1 & pil & pi:1 & pel & pi:1 & Pel & pi:1 & pi:1 & pi:1 \\
\hline /a:/ & $\mathrm{S} 1$ & S2 & S3 & S4 & S5 & S6 & S7 & S8 & S9 & S10 \\
\hline half & ha:f & ha:f & ha:f & ha:f & ha:f & ha:f & ha:f & ha:f & ha:f & ha:f \\
\hline laugh & la:f & lof & la:f & la:f & la:f & la:f & la:f & la:f & la:f & la:f \\
\hline draft & dra:ft & dra:ft & dra:ft & dra:ft & dra:ft & dra:ft & dra:ft & dra:ft & dra:ft & dra:ft \\
\hline last & la:st & $1 \Lambda \mathrm{st}$ & la:st & la:st & $1 \Lambda \mathrm{st}$ & la:st & la:st & lost & la:st & læst \\
\hline /a:/ & S11 & S12 & S13 & S14 & S15 & S16 & S17 & S18 & S19 & S20 \\
\hline half & ha:f & ha:f & ho:f & ha:lf & hæf & ha:f & ha:lf & ha:f & ha:f & ho:f \\
\hline laugh & læf & la:f & $1 \Lambda f$ & la:f & la:f & læf & ləo & la:f & la:f & la:f \\
\hline draft & dra:ft & dra:ft & dra:ft & dra:ft & dræft & dræft & dra:ft & dra:ft & dra:ft & dra:ft \\
\hline last & la:st & la:st & Læst & la:st & læst & læst & la:st & la:st & la:st & la:st \\
\hline$/ \mathbf{0}: /$ & S1 & S2 & S3 & $\mathrm{S} 4$ & S5 & S6 & S7 & S8 & S9 & S10 \\
\hline law & ləu & ləu & b: & lov & 10: & 10: & lav & lo: & ləu & lav \\
\hline caught & $\mathrm{k} \Delta \mathrm{t}$ & kpft & ko:t & ks:t & $\mathrm{kpt}$ & ks:t & ku:t & ko:t & kəort & kavt \\
\hline corn & $\mathrm{k} \Lambda \mathrm{rn}$ & ko:n & ko:n & ko:n & ko:n & ko:n & ko:n & kprn & ko:n & ko:n \\
\hline forge & fo:ds & fo:ds & fa:ds & fo:ds & fo:ds & f3:rds & fo:ds & fo:ds & fo:ds & fə:rg \\
\hline$/ \mathbf{0}: /$ & S11 & $\mathrm{S} 12$ & S13 & S14 & S15 & S16 & S17 & S18 & S19 & $\mathrm{S} 20$ \\
\hline law & lav & ləu & lu: & ləu & ləu & ləo & lav & ləu & lu: & ləu \\
\hline caught & kəut & ka:ft & kəut & $\mathrm{k} \wedge \mathrm{t}$ & ka:t & kəut & kəot & ka:f & kut & kəot \\
\hline corn & k3:r & ko:n & ko:n & ko:rn & ko:n & ko:n & kprn & ko:n & ko:n & ko:n \\
\hline forge & f3:rds & fo:ds & fo:ds & forg & forg & fog & furrt & frok & fo:ds & fo:ds \\
\hline /u:/ & S1 & S2 & S3 & S4 & S5 & S6 & S7 & S8 & S9 & S10 \\
\hline pool & pol & pol & pu:1 & pu:1 & pol & pu:1 & pu:1 & pu:1 & pu:1 & pu:1 \\
\hline flute & fl $\Lambda \mathrm{t}$ & flout & fl $\Lambda \mathrm{t}$ & flu:t & flpt & flu:t & flu:t & flu:t & flu:t & flo:t \\
\hline lose & $\operatorname{los}$ & lu:s & lu:s & lu:z & lps & lu:z & lu:z & ləuz & lu:z & lu:z \\
\hline soup & $\mathrm{s} \wedge \mathrm{p}$ & səop & su:p & su:p & sup & su:p & su:p & su:p & su:p & spp \\
\hline /u:/ & S11 & $\mathrm{S} 12$ & S13 & S14 & S15 & S16 & $\mathrm{S} 17$ & S18 & S19 & $\mathrm{S} 20$ \\
\hline pool & pu:1 & ppl & pol & pol & po:1 & pu:1 & pu:1 & pu:1 & pol & pol \\
\hline flute & flpt & flu:t & flout & flu:t & fələut & flpt & flu:t & flu:t & fla:t & flu:t \\
\hline lose & $\operatorname{los}$ & $\operatorname{los}$ & $\operatorname{lbz}$ & lu:z & la:s & 10:s & $\operatorname{lns}$ & ləoz & lu:z & $\operatorname{los}$ \\
\hline soup & $\mathrm{s} \Lambda \mathrm{p}$ & su:p & səup & su:p & su:p & su:p & spp & su:p & su:p & səup \\
\hline /3:/ & $\mathrm{S} 1$ & S2 & S3 & S4 & S5 & S6 & S7 & S8 & S9 & $\mathrm{S} 10$ \\
\hline certain & setən & serten & sertən & sertən & sertən & s3:tən & sertein & sertən & sertən & setən \\
\hline burn & b3:n & b3:n & b3:n & b3:n & bo:rn & b3:n & born & b3:n & bern & b3:n \\
\hline work & w3:k & w3:k & wo:k & w3:k & wo:rk & w3:k & wu:rk & work & w3:k & wo:k \\
\hline worse & wo:rs & w3:s & wu:rs & wu:rs & wo:rs & w3:s & wo:s & wo:rs & werəs & w3:s \\
\hline /3:/ & S11 & S12 & S13 & S14 & S15 & S16 & S17 & S18 & S19 & $\mathrm{S} 20$ \\
\hline certain & s3:teIn & sertən & sertən & sertən & setən & sertən & sertən & sertən & setən & sertən \\
\hline burn & b3:n & bo:rn & Ben & b3:rn & $\mathrm{b} \Lambda \mathrm{rn}$ & bern & b3:n & b3:n & bern & bern \\
\hline work & wu:k & wo:k & w3:k & w3:rk & wo:k & wu:rk & wu:rk & wo:k & wo:rk & w3:k \\
\hline worse & wo:rs & wo:rs & wo:rs & w3:rs & wu:rs & wu:s & wu:rs & wo:s & wo:rs & w3:s \\
\hline
\end{tabular}




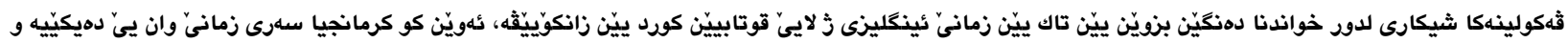

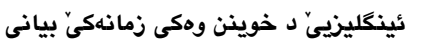

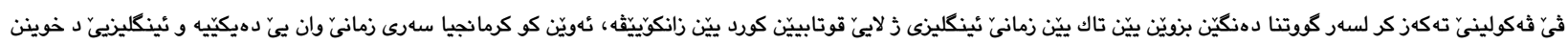

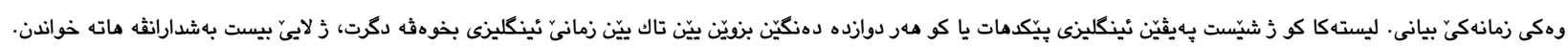

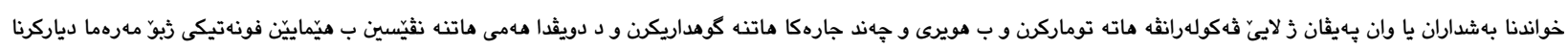

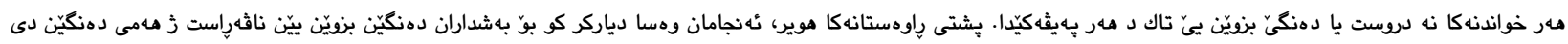

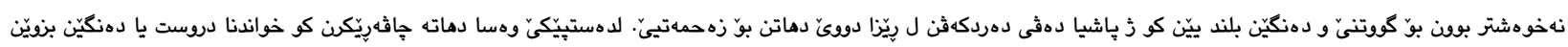

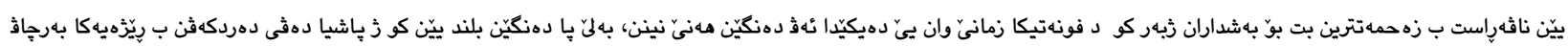

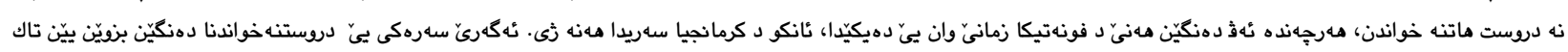

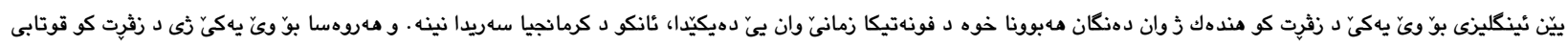

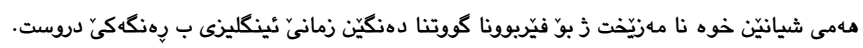

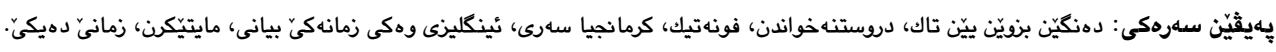

تمليل لفظ الأصوات العلة الفردية للغة الانجليزية من قبل طلاب أكراد الناطقين باللهجة الكرمانجية الشمالية، متعلمي اللغة الإنجليزية كلغة أجنبية

تناولت هذه الدراسة إنتاج أصوات العلة الفردية لللغة الإنجليزية من قبل متعلمي اللغة الإنجليزية كلغة أجنبية على المستوى الجامعي. قرأ عشرون طلاب أكراد الناطقين باللهجة الكرمانجية الشمالية,

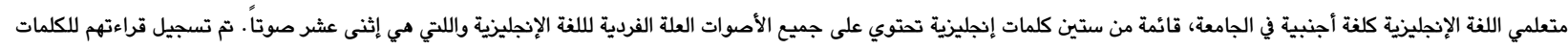

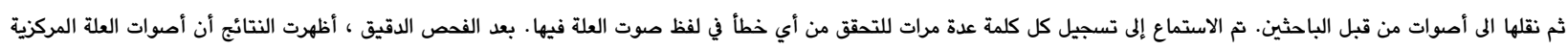

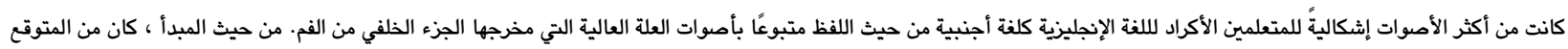

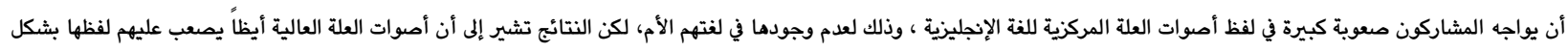

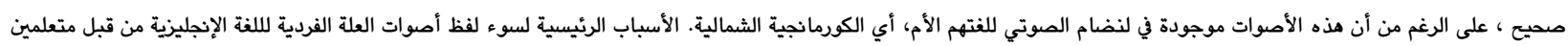

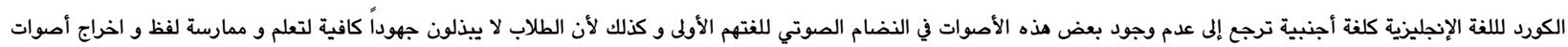
اللغة الإنجليزية. الكلمات الدالة: أصوات العلة الفردية، سوء اللفظ، النضام الصوتي، الكرمانجية الشمالية، الانجليزية كلغة أجنبية، التدخل، لغة الأم. 